\title{
The Effect of Intra-Generational Differences on the Ego States of Millennial Leaders in Indian Software Industry
}

Dr. N. Bargavi, Associate Professor, Department of Management Studies, Bharath Institute of Higher Education \& Research, Chennai, India.

\begin{abstract}
Each person has a favorite ego state which they exhibit the most, or prefer the most, depending on the situations they face and the people they interact with. People belonging to different generations react differently to different situations based on their states of ego. This paper has classified the millennial generation into Early millennial leaders (Y1) and Late millennial leaders (Y2) based on suitable findings from the literature. Further, this paper intends to explore whether Millennial generation leaders differ in ego states within their generation. The study is carried out in convenient sampling method by collecting responses from 489 Millennial leaders working in the Indian software industry. Ego State Questionnaire- Revised [ESQ-R] is utilized to survey the sample population and MANOVA is performed to assay the ego differences within the generation. It is found that the Early millennial leaders exhibited parent ego and adult ego states whereas the Late millennial leaders exhibited child ego state. Future studies can be conducted in multi-generational context and can include gender-specific research to probe whether ego states differ between males and females..
\end{abstract}

Keywords: I.T industry, Transactional analysis, Ego states, Millennials Leaders, Interpersonal relations

\section{Introduction}

The present workplace scenario comprises of workers who belong to multifarious generations starting from Baby Boomers to Zillennials. A generation is a wide term and this is the cause behind why intersecting the year of characterizes every age (Breyer, 2013). The generational partners consisted of the Veterans (1922-1945), Baby Boomers (1946-1964), Generation X (1965-1979) and the Millennials (1980-2001) (Strauss and Howe, 1991). This ubiquity of multigenerational labor force can be found at the global workplace. But, generational differences and their outcomes are sparsely discussed in the context of leadership and groups. The persisting plausibility is that four generations of people work together at the same time in the global workforce. This gives rise to the need for focusing on differences in their personality traits, behavior and attitude at the workplace. In today's global context, generations like Silent cohorts or Baby Boomers would have retired as more Millennials and Zillennials have entered the workplace (Levack, 2007). The Bureau of Labor Statistics alleged that Baby Boomers constituting to more than 76 million will relieve their jobs to younger counterparts (Kay and Cohen, 2008); leading to sixty percent of workforce comprising of Generations X and Y (Martin and Tulgan, 2001; Westerman and Yamamura, 2007). Particularly, with a gradual increase of Gen Y's in the workforce ratio, Millennials are assigned greater responsibilities and they tend to take up leadership roles (Anantatmula and Shrivastav, 2012). Previous studies have portrayed that Millennials enter the workplace with a peculiar outlook, having a unique approach in the way they work, communicate, mingle with others and create group cohesion. They adapt methods that are not often familiar to other generational cohorts and their style can lead to apprehension among other generational cohorts (Pooley, 2005). Reviewing that projects, tasks and other organizational objectives need to be accomplished for an organization's success; it is critical that companies engage young generational leaders to productively complete tasks before the stipulated time.

With years flying away like minutes, numerous organizations in different ventures like Engineering, Retailing, Energy, Manufacturing and so forth have expressed that $70 \%$ of their labor force will retire in the following years (Hagemann and Stroope, 2013). This portrays the huge degree of possibilities for the Millennials around the world. Hence, it is important to understand the ego states of this generation and the life positions in which they travel at work. With a paradigm shift in generations at the global workplace, an ascent of Millennials coming up the leadership ladder can be seen in various organizations (Breyer, 2013). Therefore, it is necessary to understand that the personality of Millennial leaders can be manifested in three ego states (parent-ego, adult-ego and child-ego) and these ego states merge with one another during transactional analysis (Berne, 1972; Stewart and Joines, 1987).The analysis of these transactions between Millennials presents theory in practice. During this effective interaction, there is an interplay of five ego states (two parent-ego, one adult-ego and two child-ego states) during work in which Gen Y leaders exhibit different behaviors (Shrivastava and Midha, 2016; McLeod, 2009; Stewart and Joines, 1987)

As a subject-matter, generational differences are not yet properly conceived. It is a pre-requisite which is critical for managerial research and further studies (Westerman and Yamamura, 2007). Cognition on the differences among various generations in the workplace will enable leaders to take important decisions on 
human resourcing policies and help them to formulate strategies and practices accordingly (Sullivan et al., 2009). These prime findings along with previous literature works highlight the significance of this research paper. Particularly, these parities and disparities presume high importance in the context of management as organizations are managed and led by leaders from diverse backgrounds and disciplines. As Millennials move into leadership positions at workplace, it is critical to understand how the Gen Y's will adapt to changes at work and how work practices will change to adhere to the Millennial's needs. This forms as a background of this study, revealing the behavioral characteristics of Millennials who are designated as leaders at the workplace. This paper intends to provide organizations with knowledge related to Millennial leaders that will enhance their understanding on issues about their dominant ego states; as a result of which they exhibit different behaviors at work. Also, this study may also help organizations to identify new perspectives on the Millennial leader's states of ego which evince at the workplace and infer them to formulate suitable strategies.

In the next phase of this paper, a detailed literature review about different generations and their ego states are explained. The methodology and design section highlights about the different traits showcased by different intragenerational leaders and the survey is outlined based on the findings from literature works. Millennial leaders are the respondents who work as team leaders and higher leadership roles in the I.T industry in India. Post a careful evaluation of survey results and previous works as stated in the review of literature, findings and discussions are presented in the following sections of this paper; concluding with suggestions for future research.

\section{Review of Literature}

\section{Generations at workplace and their attributes:}

Veterans - Known as the Silent generation, they are the oldest cohort prevailing in the global workplace. They are born between 1922-1945 (Zemke et al., 2000) having shaped by worldly historic events like the Great Depression, World Wars etc. This generation is reducing in number and is sparsely found in organizations today. They are perceived as a conservative and disciplined generation, who believe in paying their dues, and display great respect for authority, like social order, and tendency to hoard (NOAAOD, 2006). The dominant attribute of these Veterans are their preferences of job security and loyalty to the employer. They exhibit rigid work ethics and deliver respect to leaders. These cohorts dress formally and imply a formal style of communication. They become motivated to perform better when organizations listen to their suggestions and value their experience (Kogan, 2001). Their leadership style can be referred as military or commanding authoritarian style. They tend to take decisions based on their logical thinking and view conformity as success (Lyon et al., 2005).

Baby Boomers - This generation is born between 1946 and 1964 (Zemke et al., 2000). They are the first generation to experience the world via television. Mostly this generation is raised after the Second World War when the whole global economy faced affluence (Lyon et al., 2005). In a workplace, they are considered to be positive, team-bound, and the zeal to walk for the extra mile (Kogan, 2001). They exhibit good communication skills in bringing an organizational change and consensus. They are perceived as mentors because of their communal skills in organizations. They are also viewed as competitive in nature and workaholics to the extent that they are recognized by the work they do. They work based on their emotions and instincts rather than questioning and reasoning (Lyon et al., 2005). Gen X cohorts grew up in an era of prosperity and optimism. So they are encouraged by the sense that they are a special generation capable of changing the world. They consider work identity as self-worth, contribution and personal fulfilment (Yang and Guy, 2006). The reality that these cohorts hold top managerial positions at work isn't surprising due to their long working hours and continuous work dedication (Kyles, 2005). Also, they expect to stay in top designation due to poor financial planning and their desire for gratification (Coleman et al., 2006). They have been the largest generational cohort in the globe (Wong et al., 2008). The Boomers strive and live to work when compared to the Gen X individuals who work to live (Sirias et al., 2007; Sullivan et al., 2009).

Generation X - These individuals are born between 1965 and 1979 (Zemke et al., 2000). They grew up with parents where both of them worked and earned money (Lyon et al., 2005). They have witnessed layoffs, retrenchment, inflation and they have implied efforts for personal growth rather than employer's growth. They are not reluctant to use technology and adapt to it. They have witnessed divorce of their parents i.e. the Boomers due to the inefficiency in balancing work and family. These individuals desire to enjoy and have fun after workhours so that they could maintain balance between work and personal life (Kogan, 2001). They are deemed to be to be impatient with traditional ways of working, prefer to work alone, and are skeptical, although they want to learn and grow. Gen $\mathrm{X}$ individuals tend to have a practical approach and bring a realistic thought process to solve issues. They are experienced with technology, leading them to become comfortable using 
technology. They prefer working in less-hierarchical structure of organizations and strive to add value to their organizations (Lyon et al., 2005). These generational cohorts are loyal and committed to their employers whereas their younger counterparts (Gen Y's) perceive entrepreneurship and jumping from one organization to other as their career goals (O’Bannon, 2001).

Generation $Y$ - They are people born between 1980 and 2001 (Zemke et al., 2000). This generation is characterized by television, mobile phones, video games, internet and online games. Considering other generations, these cohorts also spend time in social networking through Facebook, Twitter etc., and professional networking through LinkedIn, ResearchGate etc. They are virtually connected and highly knowledgeable who are raised in diverse ethnic backgrounds. These people are flexible to any kind of situations and frequently take risks to hop on jobs regularly (Gale, 2007). They lack loyalty towards employers and are attributed as technical, adaptable and learning oriented (Deal, 2007; Dobbs et al., 2007). They received exposure to computers at very young age and facilitate information exchange in seconds (Gen Y: The Millennials, 2006). As almost the entire generation has hands-on-experience in using computers, these people are convenient with technology, open to experiences, create new ideas and are visual learners (Junco and Mastrodicasa, 2007). They challenge and strive for equal opportunities; and question a rule or procedure at work if they are uncomfortable. They are pointed as "Why" generation and don't hesitate to express their opinions. They do not adhere blindly to organizational policies (Lyon et al., 2005). From a psychological background, Millennials exhibit high self-esteem, self-centeredness, depression, anxiety, and less social approval (Twenge and Campbell, 2008). They displayed optimistic traits like resilience, efficiency, tolerance and commitment (Chester, 2002). Also, they do not find any difference between work and personal life; due to which they tend to work at any time and in any place. Their main drawback is that they desire for high managerial designations during early career itself which portrays them to be ambitious and competitive in nature. They enjoy challenges, recognition and aim to keep growing day by day. They do not stick at the same position or to the same organization and they desire to see a bigger picture by learning different tasks/functions in an organization (Pooley, 2005). Based on the previous works, literature evidences, anecdotal data and case studies, the attributes of each generation with key terms are summarized below.

Table 1. Key Traits of Each Generation

\begin{tabular}{|c|c|c|c|c|}
\hline & Veterans & Baby Boomers & Gen X & Gen Y \\
\hline Time period & $1922-1945$ & 1946-1964 & $1965-1979$ & $1980-2001$ \\
\hline Names given & $\begin{array}{l}\text { Traditionals, Matures, } \\
\text { Silent, GI generation }\end{array}$ & Baby Boomers & $\begin{array}{l}\text { Post Boomers } \\
\text { Baby Busters }\end{array}$ & $\begin{array}{c}\text { Millennials, } \\
\text { Nexters, Gen Me }\end{array}$ \\
\hline Life Events & $\begin{array}{l}\quad \text { Great Depression, } \\
\text { Second World War, GI } \\
\text { Bill }\end{array}$ & $\begin{array}{c}\text { Cold } \\
\text { Economic Prosperity }\end{array}$ & $\begin{array}{l}\text { Civil rights, } \\
\text { Vietnam } \quad \text { war, } \\
\text { Women Rights }\end{array}$ & $\begin{array}{l}\quad \text { Iraq Warfall, Hi- } \\
\text { tech revolution, } \\
\text { Internet evolution }\end{array}$ \\
\hline $\begin{array}{l}\text { Work } \\
\text { attributes }\end{array}$ & $\begin{array}{l}\text { Strong work ethics, } \\
\text { respect for leaders, } \\
\text { Authority in hands }\end{array}$ & \begin{tabular}{l}
\multicolumn{1}{c}{ Team cohesion, } \\
Optimism, Sacrifice, \\
Hard-work, Loyal
\end{tabular} & $\begin{array}{l}\quad \text { Practical, } \\
\text { Balanced work life, } \\
\text { Pessimistic, } \\
\text { Independent }\end{array}$ & \begin{tabular}{l}
\multicolumn{2}{c}{ Narcissism, } \\
Ambitious, \\
savvy, \\
tasking
\end{tabular} \\
\hline $\begin{array}{l}\text { Leadership } \\
\text { Style }\end{array}$ & $\begin{array}{l}\text { Military/Bureaucratic, } \\
\text { Chain of command }\end{array}$ & $\begin{array}{l}\quad \text { Influencing, High } \\
\text { expectations, } \\
\text { Mentoring }\end{array}$ & $\begin{array}{c}\text { Goal oriented, } \\
\text { Practical }\end{array}$ & $\begin{array}{l}\text { Flexible, Lack } \\
\text { of social grace }\end{array}$ \\
\hline Motivation & $\begin{array}{l}\text { Value of experience, } \\
\text { loyalty, perseverance }\end{array}$ & $\begin{array}{l}\text { Demonstrate } \\
\text { abilities, Bonus, } \\
\text { Incentives, Value for } \\
\text { their contribution at } \\
\text { work }\end{array}$ & $\begin{array}{l}\text { Non- } \\
\text { hierarchical } \\
\text { structure, Loyalty, } \\
\text { Time-off } \\
\text { incentive }\end{array}$ & \begin{tabular}{l}
\multicolumn{2}{c}{ Higher } \\
Designation, \\
Monetary benefits, \\
Low social \\
approval, Creativity
\end{tabular} \\
\hline $\begin{array}{l}\text { Learning } \\
\text { Style }\end{array}$ & $\begin{array}{l}\text { Classroom } \\
\text { On the job training }\end{array}$ & $\begin{array}{l}\text { Classroom } \\
\text { Instructor focused }\end{array}$ & $\begin{array}{c}\text { Technology } \\
\text { focused, Mentors }\end{array}$ & $\begin{array}{l}\text { Creative } \\
\text { thinking, } \\
\text { Learners }\end{array}$ \\
\hline
\end{tabular}

Source: Deal (2007), Dobbs et al. (2007), Gale (2007), Glass (2007), Howe et al. (2000), Houlihan (2007), Kogan (2001), Lyon et al. (2005), McGuire et al. (2007), O'Bannon (2001), Pooley (2005), Sirias et al. (2007), Smola and Sutton (2002), Sullivan et al. (2009), Timmermann (2007), Wong et al. (2008), Zemke et al. (2000, 
2001), Yu and Miller (2003) and Anantatmula and Shrivastav (2012).

\section{Generations working together in organizations:}

Table 1 outlined the similarities and differences between the prevailing generations and these facets will have a bearing when people from different generations work as leaders in organizations. Evidences from the table and previous works demonstrate that Generation $\mathrm{X}$ and $\mathrm{Y}$ are totally different from other generations in the context of work expectations, demands, values, and work styles (Kennedy, 1996; O'Bannon, 2001). It is also found that these two generations derived satisfaction from fixing goals and the intention to work in a systematic manner (Westerman and Yamamura, 2007). Although, work values keep changing with maturity of individuals, Smola and Sutton (2002) alleged that work values are strongly impacted by generational experiences. Gen Y people are more individualistic and independent in nature compared to Gen X. Perceiving the Boomers, they enjoy position, authority, power, and decision making (Kyles,2005) to promote participative styles of management which evolved during 1970's and 1980's. This style of leadership relates to aspects like interdependence, collaboration, consensus, and decision making which are key requisites for team development (Sirias et al., 2007). Considering these aspects, Gen Y shall fall behind the Boomer's expectations.

Assaying the ideals and aspirations of the Millennial generation is a key venture in today's workplace (Maxwell and Broadbridge, 2014). Presently, the Millennial generation constitutes to 34\% of the modern workforce, making them the largest cohort present in organizations globally (Thanos and Clark, 2017). It is also noticed that inter-generational friction is caused by different communication methods, work values, attitudes towards technology and work commitment. Leaders should strengthen the positive differences and overcome the negative behaviors for a harmonic work environment (DiRomualdo, 2006). When employees nurture amicable relationships with their colleagues; they tend. to deliver amazing job performance, team efficacy, and sense of belonging (Leah et al., 2017; Omilion-Hodges \&Sugg, 2018; Omilion-Hodges \& Baker, 2014). Ample literatures can be seen portraying a detachment between Millennials and other earlier generations in the context of their upbringing, values, ethics, behavior and attitudes. (Omilion-Hodges \&Sugg, 2018; Berman \& Hellweg; 1989). Even though Boomers and Gen $X$ are perceived to be perseverant, hard-working and respectful; Millennials are treated as impatient, bold and open people who are not associated with any particular group (Nahavandi, 2006; Schullery, 2013). They are viewed as independent people who think on their own, multitaskers, highly expressive, technology oriented and aggressive in nature. These disparities in behavior have influenced the way in which they interact with their superiors. There are also strong viewpoints favoring Millennials. Studies suggest that Gen Y's have exceeded the work expectations when compared to the earlier generations and they are perceived to be incredible managers in future who are motivated by work ethics (Emeagwali, 2011). They are raised with the influence of technology in their lives and do not treat computers/ electronics as something new. They see these devices as a kith and kin of their lives. Gen Y's always have the zeal to learn, face challenges at work and they like to understand the relationship between work and organizational objectives (Tulgan,2009). While discovering the Gen Y's psychological aspects, it is found that Millennials have high social needs than the previous generations (Borges et al., 2010). They get a positive energy while exhibiting managerial traits because they do not get impressed with superiors who are monotonous, issue orders, distanced and workaholics. Instead, they respect leaders who are active, trust-worthy and those who initiate open communication (Omilion-Hodges \&Sugg, 2018). As Table 1 demonstrates the dominant traits exhibited by each generation in the workplace. These differences portray multifarious opportunities for understanding and managing the traits and behavior of Gen Y leaders.

\section{Addressing differences within the generation:}

When an organization comprises of multi-generational leaders, a new approach for team building giving significance to personal values and individual identity has to be implemented (Sirias et al., 2007). There is a study revealing the fact that there are two distinct types of Millennials namely $Y_{1}$ and $Y_{2}$ (Shrivastava, 2020). This study stated that $Y_{1}$ are those cohorts who are born around 1986 and $Y_{2}$ are those cohorts who are born after 1986. It framed 1986 as a mid-year to differentiate the Gen Y's into two categories. The Generational Theory alleged that young Gen Y people will be shaped by past events of the recent ten years (Strauss and Howe, 2000; Kowske et al., 2010). This enabled us to categorize the Millennials as Elder or the Early Millennials (1980-1990), and more youthful or the Late Millennials (1991-2001) (Shrivastava, 2020). The eldest members of Gen Y would have spent around twenty years of their career and would have been placed as Leaders who administer young people at work (Kowske et al., 2010). The Early millennials accomplished the organizational objectives swiftly and climbed up the ladder of leadership at work. This intra-generation has been shaped by pampering of parents, computers from childhood and intense technological access (Niemiec, 2000). Strauss and Howe (2010) recommended that when the Early Millennials would be 18 years old in the 
year 2000, they would have possess unique personal attributes which will come out with time. Therefore, the intra-generations of Millennials consist of Early Millennials who are born between 1980-1990 and Late Millennials who are born between 1991-2001. Hence, this accurate description of Millennials by Howe and Strauss, postulated as the prime background of this study.

\section{Analyzing the ego states:}

The prime importance of this research is that there haven't been any works published highlighting the ways in which Gen Y differ in ego states. To exemplify more about ego states; Ego state is an imperative aspect of analyzing an individual's behavior because it has the ability to examine the level of interpersonal relationships exhibited by an individual. Eric Berne, the founder of Transactional Analysis, has stated that people demonstrate three sets of thoughts, feelings and behaviors at different points of time (Novey, 1997). Berne defined ego state as "a consistent pattern of feeling and experience directly related to a corresponding consistent pattern of behavior". Berne called these sets as ego states and classified them as Child, Adult and Parent Ego. People interact with each other on the basis of three psychological positions which are known as ego states. Later, Dusay (1972) indicated that Ego States divide as follows: Critical Parent and Nurturing Parent, Adapted Child and Natural Child. These ego states are behavioral patterns comprising parent ego, child ego and adult ego. The ego states are not associated with the sequential age of individuals; instead they are related with individual behavior. Hence, a person may belong to any age and he may exhibit these different ego states in varying levels. Some people may possess more adult ego, while few may display more child ego; while others may exhibit more parent ego. A stable person keeps moving from one ego state to another based on the worldly situations they see and face.

Parent ego state integrates the attitudes and behaviors of a person who served as a parent model when the individual was in childhood. These attitudes, behaviors and personality traits are observed by the individual and it is sub-consciously recorded in his mind. All these become the basic constituent of his personality. Attributes of a person who is transacting with parent ego include qualities like being over-protective, dictatorial upright and distant. Parent ego is an assimilation of rules, codes, prejudices and norms which are collected from the individual's parents or significant persons. The Parent Ego State is like a tape-recorder which recollects everything an individual stores, hears during childhood. Just like how a parent decides how one should live, behave, what's good and what's bad, how to react to different situations; people exhibiting parent ego respond to situations similarly. When people interact with Individuals possessing parent ego exhibit physical and verbal cues like wagging fingers when they don't agree, referring rules and regulations during arguments, relying on methods that were successful in the past etc. Parent ego state may be exhibited in two forms - Nurturing parent go, Regulating/Critical parent ego. Nurturing parent (NP) ego state reflects helping tendency towards both children and adults. NP comprises of feelings, attitudes and behavioral patterns that exhibit a parental role/figure that nurtures and promotes growth. Critical parent (CP) ego state projects an evaluating attitude where the individual judges the surrounding and behavior of others. CP constitutes set of feelings and behavior patterns that resembles a parental figure which criticizes, finds mistakes, stressed the societal rules and individual values (Kahler, 2008). Each individual has a peculiar parent ego state which is a combination of helping and hurting tendencies. When individuals are aware of this ego, it gives more choice over what they do (Loffredo, 1998).

Adult ego state comprises more of reasoning, seeking and giving information. An individual transacting with adult ego perceives people in equal status, worthy and as responsible human beings based on his rationality. The adult is attributed by logical aptitude and questioning of right from wrong. This state of ego can be associated with verbal and physical cues that consist of consciousness and factual reasoning. The process of forming adult ego includes going through one's own experience and regularly verifying one's own observations. Although certain values and attitudes gained during childhood are sparsely eliminated, an individual may refrain his child ego or parent ego during various phases of his life and imply his adult ego based on his experiences. He keeps constantly updating his parental ego attributes in order to assay what is right and what is wrong. Also, he updates his child ego in order to assay what feelings should he project/express. This state of ego is also called the 'computer' part of ourselves. When in the Adult Ego State, an individual offers and asks for information, and based on the data he receives, he takes decisions. Just like how the functions of an Adult is fact-based; similarly, people exhibiting adult ego tend to implement decisions based on logic and facts. When in the Adult Ego State, a person uses logical thinking to solve problems, and acts like a mediator between the Child Ego State and the Parent Ego State (Stewart and Joines, 2007) Thus, he retains those behavior which he feels is valid and he learns to control his emotions appropriately as a person exhibiting adult ego.

Child ego state comprises of traits like creativity, anxiety, conformity, being irate, dependence, fret and hatred. The cues that an individual projects in this state are silent compliance of rules, seeking attention, 
giggling and temper tantrums. The child ego is characterized by instant seeking of actions, non-logical thinking and immediate gratification. This state reflects early childhood conditions and events faced by individuals in their early years of life, before the age of five years. The child has no ability to move out to face life; so it intakes whatever comes its way. When an individual displays this state of ego, he experiences, acts, feels, thinks, hears and reacts as the child he was during a certain moment of his childhood and again enacts the same way at present. The Child Ego State is the source of feelings, intuition, needs, creativity, creation and procreation (Wadsworth and Divincenti, 2003). The Child Ego State has all the feelings one can express. There are three forms of child ego state namely natural/free-child (FC) and adaptive child (AC). The free-child ego (FC) consists of affection, sensing and impulse which is projected naturally by the child. So, the child also frets at times, indulges in self and becomes irate during unpleasant surroundings. A FC embraces feelings and attitudes that are artifacts of one's own childhood and is marked by fun, and natural, spontaneous feelings. When an individual tends to be loving, spontaneous, intuitive or playful; he exhibits the positive form of FreeChild ego. When an individual shows hatred, impulse, anger and narcissism; he projects the negative part of the Free-Child ego.

The adaptive child (AC) ego comprises of training which the parents give while raising him. AC constitutes a set of feelings characterized by compromising and conforming behaviors arising from the dominance of parental influence. When an individual is adaptive, thoughtful, creative, imaginative and a good executant; he exhibits the positive part of the Adapted Child Ego (Kahler, 2008). At the same time, a high level of Adapted Child is linked with emotional instability. When in a negative Adapted Child Ego State, a person can show discouragement or irritation in facing an obstacle, fear and helplessness, more stress in accomplishing tasks. The person can be angry, fearful, guilty or ashamed, turning the anger inwards and self-discounting, exposing a rebellious behavior (Kahler, 2008). Each individual may react to specific stimulus in the surrounding in a unique manner depending on their ego states.

Cross transactions occur when people converse from different ego states like parent to child, adult to parent, child to parent etc. In such situations, the consequences are different and there are huge chances for conflicts or misunderstandings. The below tables describes the possible transactions between the ego states and their consequences.

Table 2. Possible cross transactions of ego states

\begin{tabular}{lll}
\hline Superior & Subordinate & Consequence \\
\hline Child Ego & Child Ego & Worst situation for the organization. \\
\hline Child Ego & Adult Ego & Frustration to the subordinate. \\
\hline Child Ego & Parent Ego & Subordinate dominates the superior. \\
\hline \hline Adult Ego & Adult Ego & Ideal situation for the organization. \\
\hline Adult Ego & Child Ego & Frustration to the superior. \\
\hline Adult Ego & Parent Ego & Subordinate dominates. \\
\hline \hline Parent Ego & Parent Ego & $\begin{array}{l}\text { Competition } \\
\text { subordinate. }\end{array}$ \\
\hline Parent Ego & Adult Ego & Subordinate may not perform as expected. \\
\hline Parent Ego & Child Ego & Dependence on the superior. \\
\hline
\end{tabular}

On examining the different ego states of a person, it can be understood that a person is likely to exhibit all three ego states at different points of time in his life; and any one ego state may be predominant. The ego state exhibited by an individual can be observed in his transactions and body language (postures, gestures, cues, facial expressions). It is also understood that each ego state has pros and cons depending on the individual's gratification.

\section{Addressing the research gap:}

Considering the age of retirement in India (60 and later) and the mean age of working population, the earlier generations i.e. Veterans and Baby Boomers are excluded from this study. Also, the Millennial generation is seen working closely with their senior cohorts i.e. Gen X. It is estimated that this Gen Y people will contribute to $75 \%$ of the workforce by the year 2025 (Schawbel, 2013). It is essential to note that previous studies 
exemplify on the attributes/traits of Millennials based on the perception of earlier generations. Not even a handful number of research studies can be seen examining the concept of ego states among Millennials. This research paper utilizes quantitative, survey based evaluation to identify the dominant ego states exhibited by Millennial leaders $\left(\mathrm{Y}_{1}\right.$ and $\left.\mathrm{Y}_{2}\right)$ in understanding the mindset and behavior of the Millennial generation to efficiently manage a multigenerational workforce.

Millennials have been studied and examined in infinite ways to understand how they differ from earlier generations. But, the ego states of Millennial leaders haven't been explored earlier within the context of a specific country. Millennials exhibit different values and have distinct personality traits. Several models and theoretical concepts formed in one corner of the globe to understand the events and phenomenon that happen in the other corner has been fascinating. Many Western theories have been formulated to understand other cultures and social aspects. Hofstede's model (1983), Trompenaars's model (2004) enhanced the understanding on cultural differences based on aspects like power, individualism, distance which enables to discern national culture. Every individual's behavior is associated to their mental map that includes cognitive elements and emotional intelligence. The mental maps vary according to the surrounding in which the individual exists and people react on the basis of what they infer from their surroundings. So, it can be concluded that every person has distinct mental maps and traits; and this will enable him to interpret the same stimuli in a unique manner (Shrivastava\&Midha, 2016). Difference in values, perception, ethics, behavior, culture have stressed the importance to determine the ego states of generations and analyze their life positions. Since India is a place giving high importance to socio-cultural values; interpersonal relationships and social cohesion become an indispensable part of the culture here (Dash et al., 2007). Hence, this stresses the need for exclusive quantitative analysis of interpersonal relationships between the Millennial generation in specific Indian context. As no earlier research works have analyzed the transactional interactions of Millennials in a particular background. So, this enabled us to frame the research question stating "Do Early Millennial leaders ( $\mathrm{Y}_{1}$ ) differ from Late Millennial leaders $\left(\mathrm{Y}_{2}\right)$ in their ego states?" The next section of this paper elucidates the methodology and design of the research instrument which is outlined based on the findings from literature works.

\section{Methodology \& Design}

The incitement for this study is based on previous literatures and its findings which recommends that differences exist between one specific generation (i.e. Early Millennials and Late Millennials) and the working of this paper is stimulated by the previous finding that:

[...]The Generational Theory stated that young Gen Y people will be shaped by past events of the recent ten years (Strauss and Howe, 2000; Kowske et al., 2010). This enabled us to categorize the Millennials as Elder or the Early Millennials $Y_{1}$ (1980-1990), and more youthful or the Late Millennials $Y_{2}$ (1990-2001). Also, the Millennial generation is shaped by distinct historical/life events (Parry and Urwin, 2011; Twenge and Campbell, 2008) that has resulted in those cohorts exhibiting different ego states at work.

So, this research work intends to help organizations to understand the various ego states exhibited by Millennial leaders by evaluating their ego states displayed during work. As the focus of this study is about Gen Y leaders who work in the IT industry, this exploratory research is concentrated on determining key intragenerational differences on the interpersonal relationship of Millennial leaders. Based on the elaborate review of literature, the below hypothesis is chosen to be tested using statistical analysis:

"Early Millennial leaders $\left(\mathrm{Y}_{1}\right)$ differed significantly in their ego states when compared to Late Millennial leaders $\left(\mathrm{Y}_{2}\right)\left(\mathbf{H}_{\mathbf{1}}\right)$ "

Since this study is about intra-generational differences, examining key differences in ego phases that will influence the organizational performance is to be found. Also, it is vital to identify the preferred ego state of Gen Y leaders to improve organizational efficacy. Therefore, a research instrument is developed that comprises of the below themes.

- Respondent's demographic background consisting of their age, designation, experience, no. of projects handled and global travel for work transitions.

- Ego states exhibited by Millennial leaders at work like Nurturing Parent (NP), Critical Parent (CP), Adult (A), Free Child (FC) and Adaptive Child (AC).

These themes are based on relevant concerns that Generation Y cohorts deal with in order to enhance their role with people and the top management. Responses are sought on Likert Scale with five options namely strongly agree (5), agree (4), neither agree nor disagree (3), disagree (2) and strongly disagree (1). Demographic questions are given to receive the information on the respondent's current age and to which intra-generation 
they belong to i.e. Early Millennials or Late Millennials. It took around fifteen minutes for each respondent to complete the survey. This survey is conducted on Millennial leaders who worked in the IT industry in Chennai, India.

\subsection{Population and Sample}

Respondents - The sample comprises of N=662 Millennial Leaders working in the IT industry in Chennai, South India. Only the organizations enlisted under NASSCOM (National Association of Software and Services Companies) in Chennai were approached to collect data. The Gen Y leaders having mid-level and senior leadership roles were considered for this study. They were surveyed through the Google Forms and the research instrument is dispensed by convenient sampling method. Out of the 622 leaders to whom questionnaires were given, 514 leaders were received with a turn-in rate of $83 \%$. In these 514 reactions, only 489 responses were valid and complete without any missing values and entries. In this way, the information of $\mathrm{N}=489$ respondents are examined before the outbreak of the pandemic. It is understood that 489 samples are finite numbers that can't construe the representation of the whole population. Hence, caution is exercised while making inference of the findings from statistical analysis. The analysis is done using SPSS 23.0 and inferred underneath.

Measures - The research instrument utilized for surveying the Millennial Leaders is described by Loffredo and Harrington (2012), where each of the five ego states constitute the total score of the eight items under a particular ego state. This is given in the Ego State Questionnaire- Revised [ESQ-R]; and the same has been implemented in this study to assay the ego states of Millennial leaders. CFA was additionally performed to validate this scale which resulted in values of Normed Fit Index (NFI =0.881), Comparative Fit Index $(\mathrm{CFI}=$ 0.936), Tucker-Lewis Index values (TLI = 0.911), Standard Root Mean Square Residual (SRMR $=0.0011)$ and Root Mean Square Error of Approximation (RMSEA $=0.0366$ i.e. e<.06). These values validated the psychometric properties of the scale; substantiated by earlier literatures (Sahadev et al., 2014; Dulin, 2005; Hooper et al., 2008; Thompson, 2004). Since this study aims to explore the ego states exhibited by Millennial leaders at work, this lays the basis for a precise investigation like examining shift in ego states.

\section{Data Analysis and Interpretation}

Demographic Background of Respondents - Among the 489 respondents, 209 Millennial leaders are born during the years 1980-1984, 153 Gen Y leaders are born between 1985-1990, 116 Millennials are born during 1991-1995 and 11 respondents are born between 1996-2001.

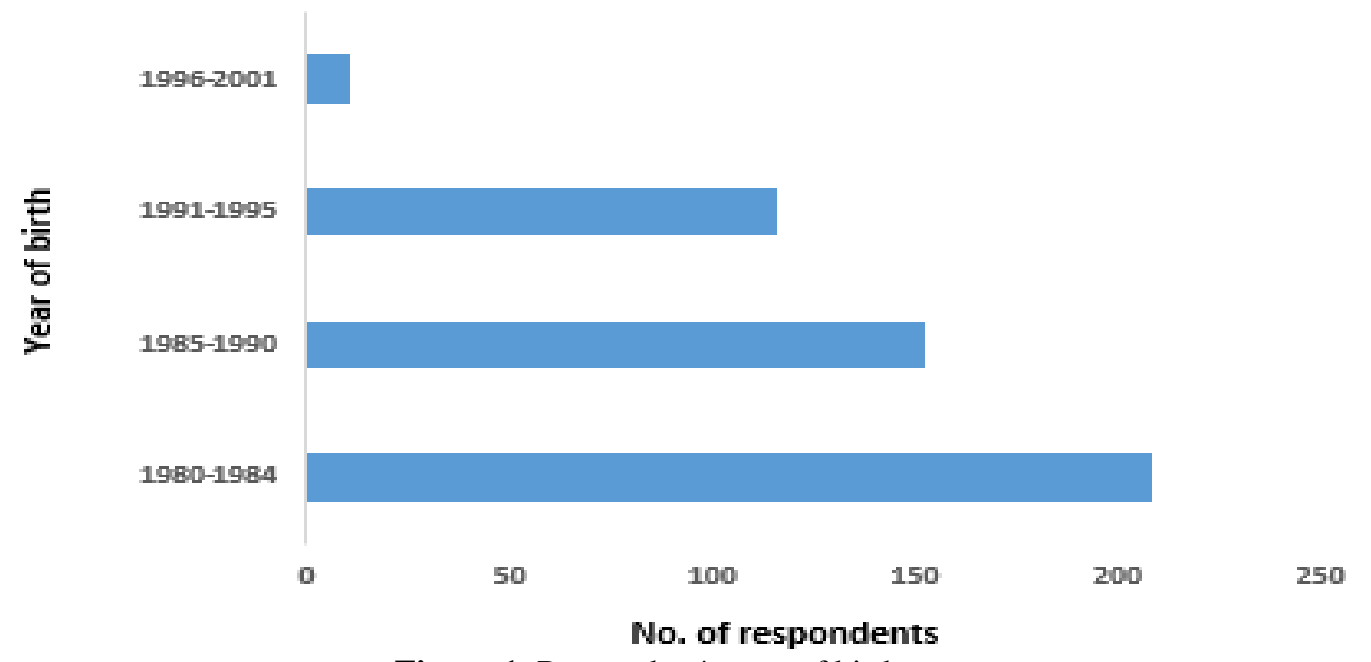

Figure 1. Respondent's year of birth

This is depicted in the figure above from which it can be understood that majority of $43 \%$ and $31 \%$ belong to the Early Millenial Leader cohorts (1980-1984 and 1985-1990), 24\% and 2\% constitute to the Late Millennial Leaders (1991-1995 and 1996-2001). It can be inferred from this result that Gen Y leaders who are born during the first five years of commencing of Millennial generation have occupied leadership positions to a greater extent when compared to those who are born later. 


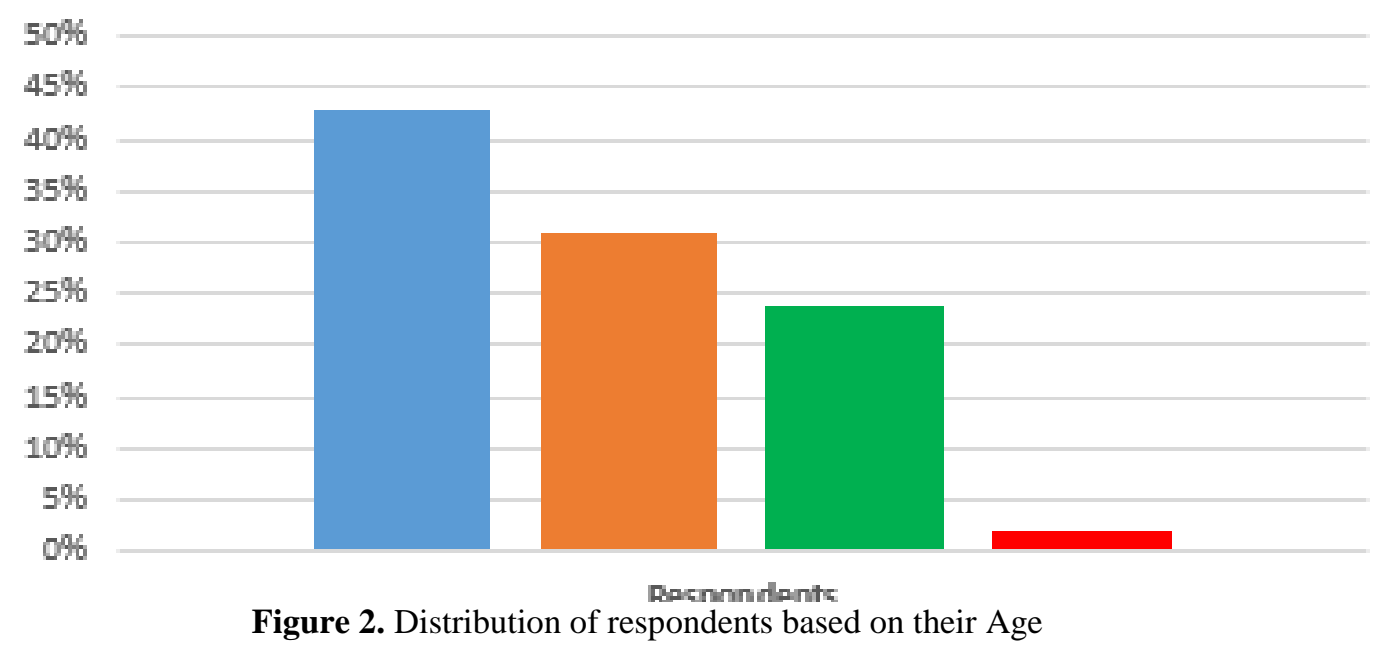

Also, it is palpable that those leaders who are born between the last five years during the culmination of the Millennial generation have constituted to a very meagre percentage. It is also depicted in Figure 2 below. This may be due to the reason that these Millennials are aged the least and they would have been designated into leadership roles at a very young age because of showcasing their talents and educational skills.

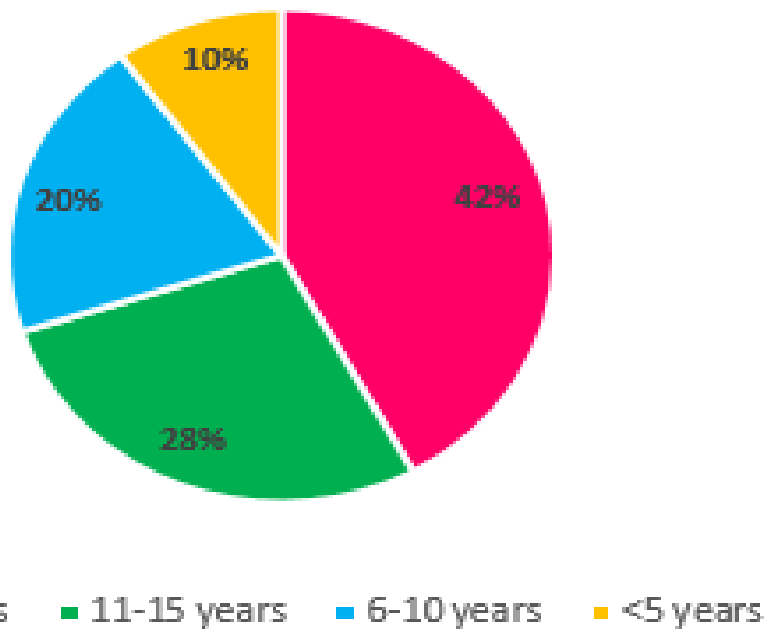

Figure 3. Experience of Respondents

Apart from the years of birth and the age of respondents, the below pie-chart (Figure 3) illustrates the experience possessed by Millennial leaders in the IT industry. Majority of the respondents i.e. $42 \%$ of the Gen Y leaders are experienced more than fifteen years, $28 \%$ are experienced between 11-15 years, 20\% are experienced between 6-10 years and 10\% are experienced below 5 years. This infers that a greater part of the sample size have a tenure of more than 15 years at work. This implies that they would have joined an organization as a contract level employee and then rose to leadership positions during the span of fifteen years. Similar results may be inferred for people with other years of experience. 


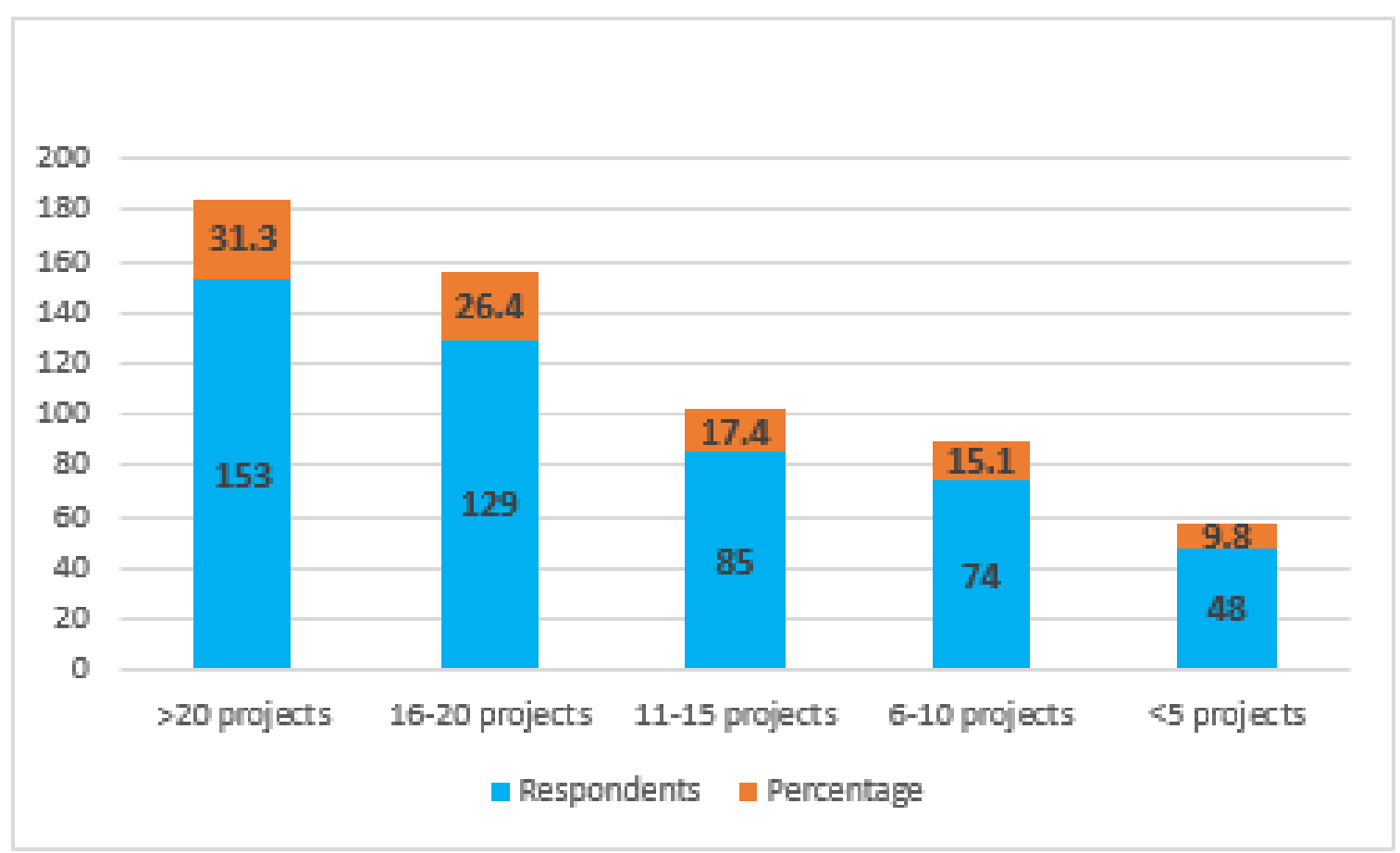

Figure 4. No. of Projects Handled

Comparing the number of respondents who handled different quantum of projects, Figure 4 depicted that out of the 489 respondents, 48 of the Millennial leaders handled below five projects, 74 of them handled six to ten projects, 85 handled eleven to fifteen projects, 129 handled sixteen to twenty projects and 153 leaders handle above twenty projects. This infers that as Gen Y leaders gained more experience within the organization; they undertook more job rotation and got specialized in handling any type of projects given by the organization. So, the years of experience is directly proportional to the number of projects handled by the Millennial leaders. Also, $46 \%$ of Gen Y leaders had travelled abroad for on-site client support and knowledge transfers, while 54\% of them are yet to go abroad for work transitions.

\subsection{Hypothesis Testing}

$\mathrm{H}_{1}$ of this study asserted that Early Millennial Leaders differed significantly in their personality traits when compared to Late Millennial Leaders. A Multivariate Analysis of Variance is performed to assess the mean differences in ego states between elder $\left(\mathrm{Y}_{1}\right)$ and younger $\left(\mathrm{Y}_{2}\right)$ Gen $\mathrm{Y}$ leaders. MANOVA is an ideal technique to diagnose the existence of mean differences in continuous dependent variables. It performs tests for mean vector's equality across groups, adding post-hoc tests to deduce which of the groups varied from others on their means (Wells, 2011). The leader's years of birth are used to classify them as Early and Late Millennials based on the Strauss \& Howe framework. This classified the Gen Y as Elder Millennials (Y 1 ) (1980-1990) and younger Millennials $\left(\mathrm{Y}_{2}\right)$ (1991-2001) (Strauss and Howe, 2000; Kowske et al., 2010). So, the predictors are fixed as the two different intra-generational cohorts i.e. Early Millennials and Late Millennials, whereas the 'criterion' is fixed as the five ego states i.e. CP, NP, A, FC and AC.

Table 3. Between-subjects factors

\begin{tabular}{ccc}
\hline Years & Value Label & $\mathbf{N}$ \\
\hline $\mathbf{1}$ & $1991-2001$ & 127 \\
$\mathbf{2}$ & $1980-1990$ & 362 \\
\hline
\end{tabular}

Table 2 infers the sample size of respondents in each age group. It is palpable that there are 127 Gen Y leaders in the Late millennial generation (Y1) and 362 Early Millennial Leaders (Y1). So, Millennials who are elder can be seen in leadership positions in the I.T industry. This may be due to the fact that these Millennial would have joined the workforce as employees in the beginning, and grew further with several promotions in 
their work-roles, becoming team leaders or team managers at work. This may be one of the reasons due to which a higher number of Millennial who are born early during 1980-1990 are omnipresent in the I.T industry.

Table 4. Descriptive Statistics

\begin{tabular}{lcccc}
\hline Personality Traits & Years & Mean & SD & N \\
\hline Nurturing Parent Ego (NP) & $1991-2001$ & 3.814 & 0.60 & 127 \\
& $1980-1990$ & 3.930 & 0.54 & 362 \\
Critical Parent Ego (CP) & $1991-2001$ & 3.634 & 0.71 & 127 \\
& $1980-1990$ & 3.810 & 0.83 & 362 \\
Adult Ego (A) & $1991-2001$ & 3.856 & 0.64 & 127 \\
& $1980-1990$ & 4.039 & 0.72 & 362 \\
Free-Child Ego (FC) & $1991-2001$ & 3.574 & 0.70 & 127 \\
& $1980-1990$ & 3.513 & 0.74 & 362 \\
Adaptive Child Ego (AC) & $1991-2001$ & 3.111 & 0.76 & 127 \\
& $1980-1990$ & 3.109 & 0.71 & 362 \\
\hline
\end{tabular}

Table 4 illustrates the mean and standard deviation of different ego states exhibited by Gen Y leaders. The mean scores are used to compare which age group differs in their ego states. The Early Millennial leaders $\left(\mathrm{Y}_{1}\right)$ gained high points in adult ego $(\mathrm{M}=4.039)$, nurturing parent ego $(\mathrm{M}=3.93)$ and critical parent ego $(\mathrm{M}=3.810)$. The Late Millennial leaders $\left(\mathrm{Y}_{2}\right)$ scored high in Free-child ego $(\mathrm{M}=3.574)$ and Adaptive child ego $(\mathrm{M}=3.111)$.

Table 5. Box's test of equality of covariance matrices

\begin{tabular}{ll}
\hline Variables & Values \\
\hline Box's M & 35.167 \\
F & 1.729 \\
df $_{\mathbf{1}}$ & 21 \\
df $_{\mathbf{2}}$ & 354859.420 \\
Sig. & 0.048 \\
\hline
\end{tabular}

Design: intercept + Gen Y years

The Box's test highlights the equality of co-variance results, which has to be non-significant in the case of MANOVA as it is an assumption in MANOVA, testing the null hypothesis that the observed dependent variable's covariance matrices are equal across groups. If they are not the same, it infers that the significance value is less than 0.05 and the equality of covariance matrices are not satisfied. From table 5, it is apparent that $\mathrm{F}(21,354859.42)=1.729, \mathrm{p}(.048)>\alpha(0.05)$. This fulfills the criteria that the equality of covariance is nonsignificant and thus the null hypothesis of equality is accepted.

Table 6. Multivariate Tests

\begin{tabular}{lcccccccc}
\hline $\begin{array}{c}\text { Gen Y years/ } \\
\text { Effects }\end{array}$ & Values & $\begin{array}{c}\text { F- } \\
\text { value } \\
\mathbf{s}\end{array}$ & $\begin{array}{c}\text { Hypothesis } \\
\mathbf{d f}\end{array}$ & $\begin{array}{c}\text { Error } \\
\mathbf{d f}\end{array}$ & Sig. & $\begin{array}{c}\text { Partial } \\
\boldsymbol{\eta}^{2}\end{array}$ & $\begin{array}{c}\text { Noncent } \\
\text { paramete } \\
\mathbf{r}\end{array}$ & $\begin{array}{c}\text { Observed } \\
\text { power }^{\mathbf{C}}\end{array}$ \\
\hline Pillai's trace & 0.028 & $2.511^{\mathrm{b}}$ & 6 & 482 & 0.001 & 0.025 & 15.043 & 0.832 \\
Wilk's Lambda & 0.971 & $2.511^{\mathrm{b}}$ & 6 & 482 & 0.001 & 0.025 & 15.043 & 0.832 \\
Hotelling'strace & 0.029 & $2.511^{\mathrm{b}}$ & 6 & 482 & 0.001 & 0.025 & 15.043 & 0.832 \\
\hline
\end{tabular}




\begin{tabular}{lllllllll}
\hline $\begin{array}{l}\text { Roy's largest } \\
\text { root }\end{array}$ & 0.026 & $2.511^{\mathrm{b}}$ & 6 & 482 & 0.001 & 0.025 & 15.043 & 0.832 \\
\hline
\end{tabular}

${ }^{\mathrm{a}}$ Design: intercept + Gen Y years, ${ }^{\mathrm{b}}$ Exact statistic, ${ }^{\mathrm{c}}$ Computed using alpha $=0.05$

Table 6 gives a summary of Multivariate analysis results that is inferred through the Pillai's trace. Pillai's trace protects from rejecting the null hypothesis when it is actually true. Pillai's trace is smaller and highly robust to violations of assumptions in covariance. The tabulated values show the MANOVA value of 0.001 and actual $\mathrm{F}$ value is 2.511 , which is significant at $\mathrm{p}<.005$. This leads to the rejection of null hypothesis that there are no differences in the ego states of early and late Millennial leaders, as per the results of MANOVA. Partial Eta squared value shows 0.025 which infers $2.5 \%$ of variability in the ego states in a canonical MANOVA is accounted by the Millennial's year of birth. This leads to the rejection of null hypothesis $\left(\mathrm{H}_{\mathbf{o}}\right)$, proving that there is a statistically significant difference in the ego states of Millennial leaders based on whether they are Early Millennial leaders or Late Millennial leaders, $F(6,482)=2.511, p<.005$; Wilk's $\Lambda=0.971$, partial $\eta \mathbf{2}=\mathbf{. 0 2 5}$. Hence, the Early Millennial Leaders differed $\left(\mathrm{Y}_{1}\right)$ significantly in their parent and adult ego states when compared to the Late Millennial Leaders $\left(\mathrm{Y}_{2}\right)$.

Table 7. Levene's test of equality of error variances

\begin{tabular}{lcccc}
\hline Ego States & F-Values & $\mathbf{d f}_{\mathbf{1}}$ & $\mathbf{d f}_{\mathbf{2}}$ & Sig. \\
\hline Nurturing Parent Ego (NP) & 1.811 & 1 & 487 & 0.007 \\
Critical Parent Ego (CP) & 12.012 & 1 & 487 & 0.274 \\
Adult Ego (A) & 1.169 & 1 & 487 & 0.001 \\
Free-Child Ego (FC) & 5.613 & 1 & 487 & 0.017 \\
Adaptive Child Ego (AC) & 0.965 & 1 & 487 & 0.322 \\
\hline
\end{tabular}

Design: intercept + Gen Y years

Further, Levene's test of Equality of Error Variances is also performed in Table 7 to check the Assumption of Homogenous Variance. Levene's test is a basic criteria for a test of equality that a statistically significant difference exists between the means of two or more groups during the analysis of variance. Here, the Levene's values demonstrated that certain traits like openness, agreeableness, conscientiousness, and emotional stability proved to be significant with $\mathrm{F}(1,487), \mathrm{p}<.05$. Hence, the test for null hypothesis of equal error variance $\left(\mathrm{H}_{\mathbf{0}}\right)$ across personality traits is rejected, resulting in testing each dependent variable with a series of ANOVA's. Levene's test reconfirmed that the Elder Millennial Leaders $\left(\mathrm{Y}_{1}\right)$ possessed different personality traits when compared to Younger Millennial Leaders $\left(\mathrm{Y}_{2}\right)$.

Table 8. Tests of between-subjects effects

\begin{tabular}{llccccc}
\hline \multirow{2}{*}{ Source } & \multicolumn{1}{c}{ Dependent Variable } & $\begin{array}{c}\text { Type 3 } \\
\text { sum of } \\
\text { squares }\end{array}$ & df & $\begin{array}{c}\text { Mean } \\
\text { square }\end{array}$ & $\begin{array}{c}\text { F- } \\
\text { values }\end{array}$ & Sig. \\
\hline & Nurturing Parent Ego (NP) & 2.752 & 1 & 2.752 & 7.450 & 0.007 \\
Gen & Yritical Parent Ego (CP) & 1.584 & 1 & 1.584 & 2.168 & 0.042 \\
years & Adult Ego (A) & 4.512 & 1 & 4.512 & 8.712 & 0.003 \\
& Free-Child Ego (FC) & 3.29 & 1 & 3.299 & 4.754 & 0.030 \\
& Adaptive Child Ego (AC) & 0.917 & 1 & 0.877 & 1.037 & 0.771 \\
\hline
\end{tabular}

${ }^{a}$ Design: intercept + Gen Y years, ${ }^{b}$ Exact statistic, ${ }^{c}$ Computed using alpha $=0.05$

Table 8 demonstrates the test of between subject effects that shows a synthesized output of one-way anova for every outcome in the Manova. The homogeneity of variance results can be matched with the values shown in this table. Three ego states like Nurturing parent ego $\mathrm{F}(3,485)=7.45, \mathrm{p}>.05$; Critical parent ego $\mathrm{F}(3,485)=2.168, \mathrm{p}>.05$; and adult ego $\mathrm{F}(3,485)=8.712, \mathrm{p}>.05$ showed statistical significance while the 
remaining two ego states didn't show any significant results. Thus, alternative hypothesis is accepted stating that there is a significant difference in the ego states exhibited by Early and Late Millennial leaders. As there are no previous studies relating to the Millennial generation and their ego states, this is a relatively new finding arising from this study. Hence, it can be surmised that the Early i.e. the Elder Millennial leaders $\left(\mathrm{Y}_{1}\right)$ significantly differ in ego states like parent ego and adult ego while the Late Millennial leaders $\left(\mathrm{Y}_{2}\right)$ differed in ego states like free child and adaptive child egos.

\section{Discussions}

There are earlier literature works which state that there are individual differences within the generations, which resulted in the formation of groups like 'early', 'middle', and 'late' groups (Kowske et al., 2010). In this research study, these individual differences within the Millennial generation is examined to determine their ego states. It is palpable that the Early Millennial leaders (elder) scored high in ego states like adult ego and parent ego. This infers that as Early Millennial leaders (Y1) are older by a span of ten years and that is the reason why they have attained maturity. These cohorts have dominant personality traits like openness, conscientiousness, agreeableness and emotional stability (Bargavi et al., 2017). Each person has a favorite ego state which they exhibit the most, or prefer the most, depending on the situations they face and the people they interact with (Ciucur D, 2013). So, the Early Millennial leaders would have joined work before two decades and they would have got molded by workplace experiences. They would have faced several pleasant and unpleasant situations and would have shaped their individual behavior accordingly. This has made them to exhibit adult ego state. Similarly, the Y1 cohorts also exhibited parent ego states. As the Y1 cohorts progress through struggles in during their tenure and become leaders; they would get a team of members assigned underneath to work and complete the organizational tasks. So, the Early Millennial leaders tend to exhibit their nurturing parent ego by nourishing young talents and while guiding their team members like a parent; by preaching them how to behave in a workplace, how to follow organizational values, how to work in cohesion with team members. Also, the Early Millennial leaders displayed critical parent ego when their team members did mistakes in their routine tasks, when their team members couldn't organize their works on priority, when their team members couldn't complete the work within stipulated timelines etc. The Y1 leaders undertook the role of a critic in supervising their team members and making them to do the assigned tasks effectively. This justifies the finding which has been projected from the analysis above that Early Millennial leaders differed in their ego states from the younger ones and they exhibited ego forms like Adult ego and Parent Ego.

Meanwhile, taking into consideration the Late Millennial leaders (Y2); it can be inferred from the findings that the younger leaders tend to exhibit child ego states. It is palpable that child ego states are of two forms namely free-child and adaptive child. As the younger millennial leaders are born between 1991-2001; they would have joined the workplace approximately before a decade and would have climbed the ladder of leadership very recently. So, their scope of exhibiting leadership skills earlier has been limited in nature. Also, since their leadership role would have been designated recently; they would behave slightly immature. Just like how a child responds; the Millennial cohorts who display child ego tend to act, feel, think, hear and react as a child. As the child ego state represents an individual's life events refined through his/her personal perception. This state of ego is the source of feelings, needs, thoughts, intuition, emotion and procreation (Wadsworth and Divincenti, 2003). The child ego state makes an individual to express all his feelings. Therefore, it can be resonated why the Late Millennial leaders tend to exhibit child ego. This specific intra-generational aspect of Millennial leaders hasn't explored earlier but similar findings are found with older individuals exhibiting positive feelings, openness and emotional stability (Carstensen et al., 2011; Riediger et al., 2009, Heyer, 1979). The level of flexibility of an individual increases gradually as he starts adapting himself to the organizational culture and work environment (Carstensen et al., 2011). Since the younger millennial leader's resilience is low, they tend to exhibit child ego more.

\section{Limitations \& Scope for further research}

While elucidating about the ego states of intra-generational Millennial leaders, one of the restrictions of this study is the elimination of multi-generational data. Here, Millennial leaders are categorized into two groups as per their year of birth, expounding their age. Earlier literature works stated that there were individual differences within the generations, which resulted in the formation of groups like 'early', 'middle', and 'late' groups (Kowske et al., 2010). It is complicated to ascertain if differences among intra-generational groups i.e. the early or late Millennials is caused really by age or intra-generational disparities. It cannot be judged whether are there any chances that the younger Millennial leader's (1991-2001 born) exhibit parent ego or adult ego states of the 
generation they are termed to be. To investigate further, a multi-generational study on different generations at work can be undertaken. An understanding of employee's state of ego can help team leaders and managers allocate appropriate individuals to various tasks (Batra and Vohra, 2016).

Another restriction of this study is that the measurement tool used was framed a long time ago. It has to be ensured whether the variables and statements hold the same significance over a period of time. Also, Millennial leaders at work have a basic limitation of age. By the time the entire generation in the workforce could be surveyed and studied, the elder cohorts would have spent twenty-one years of their job career and would be placed as leaders by supervising their younger members. In order to surmount this limitation and resolve this dilemma, future study should explore the resilience of women leaders after three-fourths of Millennials start working. This can be implemented only by continuous assimilation of data during certain intervals; for Gen Y's to age till then.

\section{References (APA)}

A. Shrivastava and M. Midha, "Transactional style inventory - A tool to enhance interpersonal effectiveness," International Journal of Leadership, Vol. 4, No. 2, pp. 10-15, 2016.

1. Anantatmula, V.S., Shrivastav, B., (2012),"Evolution of project teams for Generation Y workforce", International Journal of Managing Projects in Business, Vol. 5 Iss 1 pp. 9 - 26.

2. Balaji, C.D., (2016), Organizational Behavior, Margham Publications, pp.13.3.

3. Bargavi, N., Samuel, A. A., \& Paul, P. J. D. (2017). Resilience of millennial leaders in the Indian IT industry. Journal of the Indian Academy of Applied Psychology, 43(2), 211-221.

4. Batra, S. and Vohra, N., (2016), "Exploring the linkages of cognitive style and individual innovativeness", Management Research Review, Vol. 39, No. 7, pp. 768 - 785.

5. Berman, S.J., and Hellweg, S.A., "Perceived supervisor communication competence and supervisor satisfaction as a function of quality circle participation,” J. Bus. Commun., vol. 26, no. 2, pp. 103-122, 1989.

6. Berne, E. (1970). Games people play. New York: Grove Press.

7. Borges, N.J., R. S. Manuel, C. L. Elam, and B. J. Jones, 2010, "Differences in motives between millennial and generation X medical students," Med. Educ., vol. 44, no. 6, pp. 570-576.

8. Breyer, M.A., (2013), "How will the Personality Traits of Millennials Systematically Change Future Leadership in Non-Profit Healthcare Organizations?" (Doctoral dissertation, The College of St. Scholastica), ProQuest.

9. Carstensen, L. L., Turan, B., Scheibe, S., Ram, N., Ersner-Hershfield, H., Samanez-Larkin, G. R., Brooks, K. P., and Nesselroade, J. R., (2011), "Emotional experience improves with age: Evidence based on over 10 years of experience sampling", Psychology and Aging, Vol. 26, No. 1, pp. 21-33.

10. Chester, E. (2002), Employing Generation Why?, Tucker House Books, Lakewood, CO.

11. Ciucur, Daniel. (2013). The ego states and the Big Five personality factors. Procedia - Social and Behavioural Sciences, 78 (2013), pp. 581-585.

12. Coleman, L., Hladikova, M. and Savelyeva, M. (2006), "The baby boomer market", Journal of Targeting, Measurement and Analysis Marketing, Vol. 14 No. 3, pp. 191-209.

13. Dash, S., Bruning, E., and Guin, K.K., "Antecedents of long-term buyer-seller relationships: A cross cultural integration,” Acad. Market. Sci. Rev., vol. 11, pp. 1-29, 2007.

14. Deal, J. (2007), Retiring the Generation Gap: How Employees Young and Old can Find Common Ground, Josses-Bass, San Francisco, CA.

15. DiRomualdo, T. (2006), "Viewpoint: geezers, grungers, genXers, and geeks: a look at workplace generational conflict", Journal of Financial Planning, Vol. 19 No. 10, pp. 18-21.

16. Dobbs, J., Healey, P., Kane, K., Mak, D. and McNamara, T. (2007), Age Bias and Employment Discrimination (Fact Sheet 2007 ), Boston College, Center on Aging and Work/Workplace Flexibility, Chestnut Hill, MA.

17. Dulin, L., (2005), "Leadership preferences of a Generation Y cohort: A mixed method investigation". Dissertation Abstracts Intranational, Vol. 66, No.7, pp. 26-33.

18. Dusay, J. M. (1972). Egograms and the "Constancy Hypothesis". Transactional Analysis Journal, Vol. 2, 37-41.

19. Emeagwali, N.S., "Millennials: Leading the charge for change," Technology, Connecting Education Careers, vol. 86, no. 5, pp. 22-26, 2011.

20. Gale, S. (2007), "Bridging the gap", PM Network, Vol. 21 No. 3, pp. 26-31.

21. Glass, A. (2007), "Understanding generational differences for competitive success", Industrial and Commercial Training, Vol. 39 No. 2, pp. 98-103. 
22. Hagemann, B. and Stroope, S., (2013), "Developing the next generation of leaders" Industrial and Commercial Training, Vol. 45, No. 2, pp. 123-126.

23. Heyer, Robert N. (1979). Development of a questionnaire to measure ego states with some applications to social and comparative psychiatry. Transactional Analysis Journal, 9(1), 9-19.

24. Hofstede, G. (1983). National cultures in four dimensions: A research-based theory of cultural differences among nations. International Studies of Management \& Organization, 13(1-2), 46-74.

25. Hooper, D., Coughlan, J., and Mullen, M., (2008), Structural equation modelling: Guidelines for determining model fit, Articles 2.

26. Houlihan, A. (2007), "Bridge the generation gaps: how to get people of different ages to work together", Ward's DealerBusiness, Vol. 41, pp. 24-5.

27. Howe, N., Strauss, W. and Matson, R.J. (2000), Millennials Rising: The Next Great Generation, Vintage Books, New York, NY.

28. Junco, R. and Mastrodicasa, J. (2007), Connecting to the Net Generation: What Higher Education Professionals Need to Know, NASPA, Washington, DC.

29. Kahler, T. (2008). The process therapy model - The six personality types with adaptations. TaibiKahler Associates, Inc.

30. Kay, B. and Cohen, J. (2008), "Safeguarding the Intellectual Capital of Baby Boomers", Training and Development, April, pp. 30-3.

31. Kennedy, M. (1996), "When a boomer meets a buster", Across the Board, Vol. 33, pp. 53-4.

32. Kogan, M. (2001), "Bridging the gap", Government Executive, Vol. 33 No. 12, p. 16.

33. Kowske, B.J., Rasch, R., and Wiley, J., (2010) "Millennials (lack of) attitude problem: An empirical examination of generational effects on work attitudes", Journal of Business and Psychology, Vol. 25, No. 2, pp. 265-279.

34. Kyles, D. (2005), "Managing your multigenerational workforce”, Strategic Finance, Vol. 87 No. 6, pp. 53-5.

35. Leah, M., Hodges, O., and Baker, C.R., "Communicating leader-member relationship quality: The development of leader communication exchange scales to measure relationship building and maintenance through the exchange of communication-based goods," International Journal of Business Communication, vol. 54, no. 2, pp. 115-145, 2017.

36. Levack, K. (2007), “Generation whisperer”, Successful Meetings, Vol. 56 No. 13, p. 21.

37. Loffredo, Donald A. (1998). The relationships among ego states, locus of control, and dogmatism. Transactional Analysis Journal, 28 (2), 171-173.

38. Loffredo, Donald A. and Harrington, Rick. (2012). Letter to the editor, Transactional Analysis Journal, 42(1), 93-96.

39. Lyon, K., Legg, S. and Toulson, P. (2005), "Generational cohorts", International Journal of Diversility in Organisations, Communities and Nations, Vol. 5 No. 1, pp. 89-98.

40. Martin, C.A. and Tulgan, B. (2001), Managing Generation Y, HRD Press, Amherst, MA.

41. Maxwell, G. A., and Broadbridge, A. (2014). Generation Y graduates and career transition: Perspectives by gender. European Management Journal, 32(4), 547-553.

42. McLeod, J. Introduction to Counselling, 4th ed. Maidenhead, UK: Open Univ. Press, 2Pooley, E. (2005), "Kids these days", Canadian Business, Vol. 78 No. 12, pp. 67-8.

43. McGuire, D., By, T. and Hutchings, K. (2007), "Towards a model of human resource solutions for achieving intergenerational interaction in organizations", Journal of European Industrial Training, Vol. 31 No. 8, pp. 592-608.

44. Nahavandi, A., The Art and Science of Leadership, 4th ed. Upper Saddle River, NJ, USA: Pearson Education, 2006.

45. Niemiec, S., (2000) "Finding common ground for all ages," Secur. Distributing Market., vol. 30, no. 3, pp. 81-84.

46. NOAAOD - The National Oceanographic and Atmospheric Association Office of Diversity. (2006). Tips to improve the interaction among the generations: Traditionalists, boomers, X'ers and nexters. [Online]. Available: https://rtc3.umn.edu/docs/2_18_Gen_diff_workplace.pdf

47. Novey, T. B. (1997). Basic definitions. Transactional Analysis Journal, Vol. 27, 156-157.

48. O’Bannon, G. (2001), "Managing our future: the Generation X factor", Public Personnel Management, Vol. 30 No. 1, pp. 95-109.

49. Omilion-Hodges, L and C. E. Sugg, "Millennials' views and expectations regarding the communicative and relational behaviors of leaders: Exploring young adults' talk about work," Bus. Prof. Commun. Quart., vol. 82 no. 1, pp. 74-100, 2018.

50. Omilion-Hodges, L., and C. R. Baker, "Every day talk and convincing conversations: Utilizing strategic internal communication,” Bus. Horizons, vol. 57, pp. 435-445, 2014. 
51. Parry, E., and Urwin, P. (2011). Generational Differences in Work Values: A Review of Theory and Evidence. International Journal of Management Reviews, 79-96.

52. Riediger, M., Schmiedek, F., Wagner, G. G., and Lindenberger, U., (2009), "Seeking pleasure and seeking pain: Differences in prohedonic and contra-hedonic motivation from adolescence to old age", Psychological Science, Vol. 20, No. 12, pp. 1529-1535.

53. Sahadev, S., Seshanna, S., and Purani, K.., (2014), "Effects of competitive psychological climate, workfamily conflict and role conflict on customer orientation", Journal of Indian Business Research, Vol. 6, No. 1 , pp. $70-84$.

54. Schawbel. D., (2013). Why you can't ignore millennials, Forbes. [Online]. Available: https://www.forbes.com/sites/danschawbel/2013/09/04/why-you-cant-ignore-Millennials/\#38 a87191207c

55. Schullery, N.M., "Workplace engagement and generational differences in values," Bus. Commun. Quart., vol. 76, no. 2, pp. 252-265, 2013

56. Shrivastava, A., (2020), "Are Millennials Communication Deficient? Solving a Generational Puzzle in an Indian Context”, IEEE Transactions on Professional Communication, Vol. 63, No. 3, pp. 259-271.

57. Sirias, D., Karp, H. and Brotherton, T. (2007), "Comparing the levels of individualism/collectivism between baby boomers and Generation X", Management Research News, Vol. 30 No. 10, pp. 749-61.

58. Smola, K. and Sutton, C. (2002), "Generational differences: revisiting generational work values for the new millennium", Journal of Organizational Behavior, Vol. 23, pp. 363-82.

59. Sullivan, S.E., Forret, M.L., Carraher, S.M. and Mainier, L.A. (2009), "Using the kaleidoscope career model to examine generational differences in work attitudes", Career Development International, Vol. 14 No. 3, pp. 284-302.

60. Stewart, I and Joines, V, TA Today: A New Introduction to Transactional Analysis. Nottingham, UK: Lifespace, 1987.

61. Strauss, W., and Howe, N. (1991). Generations: The history of America's future, 1584-2069. New York: William Morrow.

62. Strauss, W. and Howe, N., (2000), Millennials rising: The next great generation, New York: Vintage, pp. 370 .

63. Thanos, L. M., and Clark, S. D. (2017). A qualitative exploration of culturally-pluralistic segmentation among Millennials. International Journal of Marketing Studies, 9(4), 1-14.

64. Thompson, B., (2004), "Exploratory and confirmatory factor analysis: Understanding concepts and applications", APA: Washington, DC.

65. Timmermann, S. (2007), "What a difference a generation makes: how our life experiences shape our viewpoints and behaviors", Journal of Financial Service Professionals, Vol. 61 No. 3, pp. 25-8.

66. Trompenaars, F., Woolliams, P. (2004). Business across cultures. John Wiley \& Sons.

67. Tulgan, B., Not Everyone Gets a Trophy: How to Manage Generation Y. San Francisco, CA, USA: Jossey-Bass, 2009.

68. Twenge, J.M. and Campbell, S.M. (2008), "Generational differences in psychological traits and their impact on workplace”, Journal of Managerial Psychology, Vol. 23 No. 8, pp. 862-77.

69. Wadsworth, D., Divincenti, A. (2003). Core concepts of transactional analysis: An opportunity born of struggle. Transactional Analysis Journal, 33, 153-161.

70. Wells, D. D., (2011), Leadership preferences of a Generation Y African American cohort (Doctoral dissertation, Capella University) ProQuest.

71. Westerman, J.W. and Yamamura, J.H. (2007), "Generational preferences for work environment fit: Effects on employee outcomes", Career Development International, Vol. 12 No. 2, pp. 150-61.

72. Wong, M., Gardiner, E., Lang, W. and Coulon, L. (2008), "Generational differences in personality and motivation: do they exist and what are the implications for the workplace?", Journal of Managerial Psychology, Vol. 23 No. 8, pp. 878-90.

73. Yang, S.M., and Guy, M.E., "GenXers versus boomers: Work motivators and management implications," Public Perf. Manage. Rev., vol. 29, no. 3, pp. 267-284, 2006.

74. Yu, H.C. and Miller, P. (2003), "The generation gap and cultural influence - a Taiwan empirical investigation”, Cross Cultural Management, Vol. 10 No. 3, pp. 23-41.

75. Zemke, R., Raines, C. and Filipczak, B. (2000), Generations at Work: Managing the Clash of Veterans, Boomers, Xers and Nexters in Your Workplace, AMA, New York, NY. 